\title{
65 kDa Phosphoprotein Antibody
}

National Cancer Institute

\section{Source}

National Cancer Institute. 65 kDa Phosphoprotein Antibody. NCI Thesaurus. Code C141279.

Any immunoglobulin that recognizes the CMV protein $65 \mathrm{kDa}$ phosphoprotein. 